\title{
Multicultural Learning Partnerships \\ IN THE CAFÉ: INTEGRATING ICT INTO \\ Transnational Tertiary Education in \\ Australia Using the Collaborative \\ ApPLicATION FOR EDUCATION ${ }^{1}$
}

\author{
Josh McCarthy \\ University of South Australia
}

\begin{abstract}
This paper reports on using the Café: the Collaborative Application for Education as an online learning environment within the Facebook framework, for integrating international students into first year university in Australia. The Cafe, a new e-learning application, has been designed and developed not only to take advantage of Facebook's popularity and social qualities, but also to provide institutions with a dedicated e-learning environment that meets the needs of modern-day tertiary students and teaching staff. During two courses in 2013, 91 first year design students, including 24 international students participated within the e-learning environment in combination with traditional face-to-face classes. Students submitted work-in-progress imagery related to assignments, and provided critiques to their peers. The evaluation process of the e-learning application involved pre and post semester surveys providing participating students with the opportunity to critically reflect on the experience during the year. The findings of the study are discussed in light of the growing use of social media within learning and teaching in tertiary education, and the importance of providing first year students, particularly international students, with multiple means of communication with staff and peers.
\end{abstract}

KEYWORDS: Facebook, international student experience, online learning, collaborative learning, first year experience, transnational education.

\section{Introduction}

In 2007 a national study was conducted by Sawir, Marginson, Deumert, Nyland and Ramia (2008), analyzing the university experience of international students in Australia. The study highlighted various issues confronting international students studying in Australia. They note that international students plunge suddenly upon arrival at their chosen institutions into a challenging new study setting, with up to 65 percent experiencing 'relational deficit' and isolation at a time when in need of greatest support. Their loneliness is often acute, separated as they are from Australian students by language and cultural barriers. They no longer belong to the world they left behind, but in first year, do not yet belong to the world they have entered. The immense popularity of web 2.0 technologies however, offers potential solutions to such learning problems. The virtual environment and accessibility of social network sites (SNSs), such as Facebook, YouTube and Flickr, are highly effective for developing 'preliminary' relationships between local and international students as they negate key loneliness triggers such as language barriers and social inhibitions. Students can communicate at their own pace and contemplate discussion and responses, rather than being 'put on the spot' in the physical classroom.

Loneliness is most likely to occur within situations such as a lengthy absence from home or the loss of a significant other (Sawir et al, 2008), two situations students face when they study abroad. The literature on loneliness indicates personality and a loss of social networks as influencing factors,

a Correspondence can be directed to: Josh.McCarthy@unisa.edu.au 
however there are many other factors that can contribute to a student's isolation. Weiss (1973) distinguishes 'personal loneliness' and 'social loneliness'. According to Weiss, personal loneliness can be seen as the loss or lack of a truly intimate tie such as that with a parent, child or lover, and is characterized by anxiety and apprehension. International students experience personal loneliness because of the sudden loss of contact with their families. Personal loneliness can often be resolved by the instalment of an 'attachment' relationship to a significant other. Students experience social loneliness because of the sudden loss of existing social and academic networks, and is characterized by boredom and a sense of exclusion. Social loneliness can be resolved through immersion into an existing or newly formed social network, as Weiss $(1973, \mathrm{p} 150)$ notes:

Social networks provide a pool of others among whom one can find companions for an evening's conversation or for some portion of the daily round. Social isolation removes these gratifications; it directly impoverishes life.

Osterman (2000), states that being accepted, included or welcomed leads to positive emotions such as happiness, elation, commitment and calm; however being rejected, excluded or ignored leads to often intense negative feelings of anxiety, depression, grief, jealousy and loneliness. People who are very prone to loneliness are often shy, introverted, and less willing to take social risks (Hojat 1982; Stokes, 1985), and as such international students, simultaneously experiencing a new culture, environment and other learning hurdles, are most at risk. Language competence is a key factor. For students just arrived in the country this is a huge barrier, and it is crucial for universities to explore means of tackling such issues. Being able to respond to a question online, in a written manner, over a period of time, rather than verbally on the spot in the classroom, is of great benefit to commencing international students. It should also be acknowledged that international students are coming from many different cultures and backgrounds, and as such may not have many, if any, peers from their own country. Indeed some international students find themselves isolated within an already distanced group (McCarthy, 2012). Triggers for loneliness and feelings of isolation are common within both commencing and continuing international students and the results can be devastating. The experience of loneliness can trigger a withdrawal from social relationships in an effort to contain the pain, reinforcing and exacerbating social isolation. Cultural factors are often responsible for triggering loneliness and can affect international students in two distinct ways. Firstly students often miss their own cultural and linguistic setting, and being placed in an unfamiliar environment can be completely overwhelming. Secondly, while many students may find themselves in cross-cultural relationships, they are often at a lower level of empathy than same-culture relationships. More specifically, international students are disappointed by the underdevelopment of relationships with local students, and can be affected by weak institutional relationships, including the exchange in classrooms with peers, and student-teacher connections (Sawir et al, 2008).

One remedy, for loneliness within international students, is integration into an existing or newly formed social network. This enables students to interact with peers and engage with their learning. The two variables that correlate most significantly with loneliness are density and quality. Denser networks enhance a sense of belonging and reduce loneliness. The larger the network, the higher the chances of students finding like-minded peers with whom to interact. Similarly, if the network contains students of similar interests, relational goals and age brackets, the quality of the network is increased. At a first year level it is crucial to promote connections with both peers and academic staff, and to do so through fostering an environment in which students participate actively and develop a sense of belonging in both small and large group settings (Krause, 2006). Opportunities to ask questions and contribute to group discussion are particularly conducive to engagement. Organizing peer learning and study groups that extend interactions beyond classroom walls and using online resources, such as forums, social networking tools, wikis and blogs, all lead to student engagement. The goal is to build student independence and support networks as part of an integrated academic and social transition experience. From an international student perspective, developing a sense of 
belonging in the academic community is critical in supporting the adjustment to university culture in Australia, more specifically, building cross-cultural connections with local students (McCarthy, 2009). Good networks help students to feel supported and more in control (Sarason, Sarason, Gurang, 1997), and friends, both local and foreign, are the most preferred source of help for international students (Baloglu, 2000). As many commencing international students lack any close friends, it is crucial to initiate connections with their peers immediately, to foster collaborative learning and a sense of belonging in the academic community.

\section{Online Learning Environments in Facebook}

Since 2007 many SNSs have been formally and informally utilised within tertiary education, including Facebook, image-host sites Flickr and DeviantArt, video-hosting sites YouTube and Vimeo, microblogging site Twitter, and visual discovery tools Pinterest and Clipix. Flickr is an image hosting website which allows users to share photographs, and host images that they embed in other SNSs. Accessibility to Flickr has improved with the advent of an application that can be used on smart devices. YouTube is a video sharing website in which users can upload, view, rate and comment on videos. Registered users can access and analyse data regarding uploads, including number of views, peaks and valleys of view times, as well as generic user demographics. Like Flickr, YouTube can be accessed via phone or tablet through a standalone application, ensuring high availability to content. The ability to embed videos in other sites, as well as the rank and comment features, provides a strong basis for peer-to-peer learning. Pinterest is a SNS which allows users to collate media and categorise content based on specific interests. The site allows users to store images, links and videos and sort them on different pinboards.

Facebook is predominantly known as a hub of social networking activity; however it is quickly being recognised as a reputable and popular e-learning platform (Bosch, 2009; McCarthy, 2012). Since 2008, Facebook has been successfully implemented as an online learning environment within tertiary education case studies around the world (Irwin, Ball, Desbrow and Leveritt, 2012; Kenney, Kumar and Hart, 2013; Kurtz, 2013; McCarthy, 2009, 2010, 2012, 2013a; Rambe, 2012; Ritter and Delen, 2013; Shih, 2011). In a 2010 case study involving 450 first year students at an English-speaking university in South Africa, it was found that Facebook could be used to overcome a first year student's sense of psychological powerlessness, by providing students with a voice (Rambe, 2012). A key factor behind this revolution is Facebook's immense popularity. Facebook is a familiar tool, and often a part of students' daily lives (Duffy, 2011; McCarthy, 2012, 2013a, 2013b). At the time of this writing Facebook has 1.31 billion monthly active users (Statistics Brain, 2014). In a 2011 case study involving 253 students over several year levels at Griffith University in Australia, Facebook was used as an online learning environment, allowing students to interact with peers and staff to post content related to associated courses. A pre-semester survey indicated that 93 percent of participants were existing Facebook users and that 78 percent anticipated Facebook would facilitate their learning. The study found that the majority of participants visited the associated page at least once a week; the page enhanced communication and interaction between students and the course instructors; interaction with the Facebook page was easy as students were familiar with the interface; and that students were able to receive updates and information which may have been missed via other forms of communications (Irwin et al, 2012). Furthermore students can access the site using a range of devices from anywhere in the world. It is also free to use, ensuring students can connect with anyone, including global peers and industry leaders, at any time. This accessibility is often perceived by students as a significant benefit as it can allow increased communication with staff and peers, greater access to course material, connections to industry, and access to collaborative learning partners (Irwin et al, 2012; McCarthy, 2012, 2013a; Bosch, 2009). In a 2010 case study Facebook hosted an online mentor scheme for digital media students at the University of Adelaide in Australia. Throughout the semester, students posted work-in-progress imagery related to their projects and received feedback and critiques from a range of local and national industry mentors. This online learning experience 
facilitated interaction between students and industry leaders and it also provided students with the opportunity to gain insight into various digital media professions while they were still studying by forging connections with potential future employers (McCarthy, 2010). While Facebook has the potential to promote collaborative learning and interaction, outside of the immediate student cohort, traditional university online learning environments, such as learning management systems (LMSs), negate such action through their closed-system format (Wang, et.al, 2012). Students must be enrolled within the specific course in order to access the learning environment, and while this structure is well suited to housing course material, such as lecture notes and tutorials; and managing course related issues, such as assignment submissions, extension requests and course evaluations, it does not accommodate the beneficial social qualities found in Facebook (Deng and Tavares, 2013; McCarthy, 2013a). Students cannot use their LMS to interact with their global peers, or receive feedback from industry mentors, as these potential partners are not authorised to access it (McCarthy, 2010). LMSs often lack social connectivity and the personal profile spaces which today's students are familiar with (Mazman and Usluel, 2010). In contrast, students see Facebook as a self-regulated space for individual expression and collaborative learning (Rambe, 2012), and a more conducive environment for communication with staff and peers (Wang et al, 2012). The primary benefits of Facebook as a learning tool arise from its ability to enable participants, both students and staff, to share information, knowledge, and artefacts within a community (McCarthy, 2012). The ability to post content and receive feedback from a wide range of collaborators stands as one of the primary educational benefits of the site (Duffy, 2011; Richardson, 2006; McCarthy, 2013a).

There are however considerable deficiencies, both pedagogical and technical, within learning environments in Facebook, which need to be addressed. Online learning environments within Facebook are commonly created using the 'group', 'page', or 'event' applications, or a combination of the three. These applications have not been designed or created specifically to use for e-learning; they have been created to facilitate interaction between social networks, and to act as marketing tools for institutions, businesses and celebrities (McCarthy, 2013a). Furthermore, Facebook developers have consistently reshaped these applications in terms of their functionality and design, resulting in a complete lack of control over the look and operation of any potential learning environment within the site (McCarthy, 2013a). Analysis of previous case studies using Facebook as a learning environment has also indicated that students' academic activities need to be isolated from their social activities. Often, when students submit work, such as comments, images or videos, to a learning environment in Facebook, these posts will appear on their friends' news feed prompting social commentary from users outside of the student cohort (McCarthy, 2013a). This is a significant problem in using Facebook as an educational tool, as it can impact on a student's willingness to participate and as a result, can impact on their performance within the learning environment (Wang et al, 2012; McCarthy, 2012). These factors highlight the need for a dedicated e-learning application within the social networking site. Facebook's popularity, social qualities and intuitive interface make it the perfect host site for online learning, while its open accessibility ensures it has the capacity to host national and international collaborative learning partnerships. However the inconsistent functionality and poor design of its in-built tools negatively affects the overall quality of the learning environment, and as a result can weaken the student experience (McCarthy, 2012, 2013b). In 2012 a learning environment in Facebook, 'The collaborative animation forum', linked student cohorts from the University of South Australia in Australia, Nanyang Technological University in Singapore, and Penn State University in the United States. Students from the three institutions were able to post their work, critique their peers, and share ideas and techniques in animation production with their global peers. While the learning experience was predominantly well received by participants from the three institutions, some students suggested that the standard Facebook applications could be improved upon in regards to their design and performance, as one noted:

It would be good if it was more tailored to education. The idea was great but the actual Facebook page was a bit average in the layout and operation. (University of South Australia student, male, local) 


\section{Research Aims}

While the afore mentioned SNSs provide opportunities for e-learning, none provide a complete online learning environment, and there is a need for an e-learning application that takes advantage of the popularity and social qualities of Facebook, as well as the content sharing qualities of Flickr, YouTube, Vimeo and Pinterest. This application should be structured and designed specifically for e-learning; it should incorporate the interactive and community-minded aspects of other successful SNSs; it should negate the 'closed-system' format of LMSs; and it should allow participants to separate their academic and social activities should they wish. In response to these factors, as well as the pedagogical concerns of the design of standard Facebook pages, events and groups, and the continuing lack of control over their operation, a custom Facebook application - the Café: the collaborative application for education - has been designed, developed and pilot tested. This paper reports on the pilot testing of the Café used as an e-learning environment for two student cohorts from the University of South Australia in Australia in 2013. The principle aim of this paper was to assess the Café's effectiveness for providing international students with an online environment within which to interact with peers and further their understanding of course material.

\section{The Café}

'The Café' can be accessed through both Facebook and its dedicated website www.thecafeapp. com/app, and can be used on a range of devices. The Café allows a user to establish an online learning environment in the form of a 'forum' and invite participants to join. A forum can be both open and closed format, at the discretion of the forum manager, enabling the creation of both private and public online spaces. The forum manager can also change this setting at any stage, allowing open access or closed access to forums at different times. Within the forum there are four key areas: the 'pinboard', 'galleries', ' $Q$ and A', and 'MyCafe'. The pinboard acts as the home page for the forum. On the pinboard participants are able to pin images, videos, comments and links, relevant to the forum. All image, video and link-based posts contain imagery to create a more visually engaging online space, while a 'live-feed' tracks all submissions within the entire forum in real time. The galleries allow the forum manager to establish virtual gallery spaces - content pages for student submissions. Forum managers can outline the details of a gallery, such as opening and closing times, and content descriptions. Participants can then submit content, be it image, video, text or link-based. Once content is submitted to a gallery, participants can comment on, 'like' or add the submission to their personal space within the forum in 'myCafe'. The ' $Q$ and $A$ ' page acts as a discussion board for the forum, and provides participants with the opportunity to ask questions and provide responses. The final section within the application is 'myCafe'. This acts as the participants' personal space within the Café. Participants are able to collate all of their submissions within the forum. They are also able to collate, and organise into categories, submissions from other participants within the forum, as well as submissions they comment on. This supports the student by (a) facilitating personal reflection on their work; and (b) helping them to prepare for exams. It also allows the student to develop an online collection of precedents and examples to enhance their broader knowledge of the topics delivered within a course. Lastly it makes assessing the student's performance, interaction and engagement within the online learning environment much easier for associated staff by collating all of their submissions in one place.

\section{The Pilot Studies}

In 2013, 91 students from two first year courses in the Bachelor of Media Arts program at the University of South Australia participated in the pilot studies. In the first lecture of the semester, students were introduced to the e-learning environment in the Café, and shown how to access, install and use the application. Following this introduction, students were given the opportunity to take part in an anonymous pre-semester survey, hosted via Survey Monkey, to determine their 
expectations of the learning experience ahead. Students were invited to take part in the survey via the Café application and also via email. The survey remained open for a period of one week. The survey included three broad types of measures: demographic data; students' attitudes towards online learning environments in Facebook; and students' attitudes towards in class and online participation. In total 70 students participated in the survey, a response rate of 77 percent. The breakdown of student demographics within the cohort is outlined in Table 1.

Table 1. The breakdown of student demographics within the two cohorts.

\begin{tabular}{|l|c|c|c|}
\hline Demographic & Local Students & International Students & All respondents \\
\hline Number of respondents & 55 & 15 & 70 \\
\hline Gender & 30 & 8 & 38 \\
\hline Male & 25 & 7 & 32 \\
\hline Female & 7 & 2 & 9 \\
\hline Age & 32 & 13 & 45 \\
\hline $17-18$ & 9 & 0 & 9 \\
\hline $19-24$ & 7 & 0 & 7 \\
\hline $25-34$ & & & \\
\hline $35+$ &
\end{tabular}

The survey contained statements towards online learning environments in Facebook and questions related to online and in class interaction with peers and teachers. Student responses and broad agreement data are collated in Table 2 and Table 3. The data shows that participating international students much prefer to engage in academic exercises online rather than in class, with 93 percent preferring to critique their classmates' work online, 85 percent preferring to engage in academic discussions online, and 73 percent preferring to ask questions online.

Table 2. Student responses to questions and statements.

\begin{tabular}{|l|c|c|c|c|c|c|}
\hline & \multicolumn{2}{|c|}{ Local Students } & \multicolumn{2}{c|}{$\begin{array}{c}\text { International } \\
\text { Students }\end{array}$} & \multicolumn{2}{c|}{ All Students } \\
\hline Topic & Yes & No & Yes & No & Yes & No \\
\hline $\begin{array}{l}\text { Have you used Facebook for any form of } \\
\text { online or collaborative learning in the past? }\end{array}$ & $42 \%$ & $67 \%$ & $33 \%$ & $67 \%$ & $40 \%$ & $60 \%$ \\
\hline Topic & In Class & Online & In Class & Online & In Class & Online \\
\hline I prefer asking questions & $44 \%$ & $56 \%$ & $27 \%$ & $73 \%$ & $40 \%$ & $60 \%$ \\
\hline I prefer critiquing my classmates' work & $18 \%$ & $82 \%$ & $7 \%$ & $93 \%$ & $16 \%$ & $84 \%$ \\
\hline Engaging in academic discussions & $49 \%$ & $51 \%$ & $15 \%$ & $85 \%$ & $41 \%$ & $59 \%$ \\
\hline
\end{tabular}

The participating international students also responded positively towards the idea of using Facebook as host site for an online learning environment. All international students were looking forward to using the Café learning environment prior to the start of the semester, while 80 percent believed Facebook was an effective host site.

During the semester students were required to regularly submit work-in-progress imagery related to major assignments, and provide feedback and critiques to their peers. Participation within the Café was worth 15 percent of the final grade for the course, and students were assessed on three key components: (a) the quality of the submitted imagery; (b) the descriptions that accompanied 
the submitted imagery; and (c) the quality and consistency of their peer critiques. Figure 1 (left) shows a screen capture from the forum's pinboard, accessed in October 2013. The screen capture shows a custom banner at the top of the page, created by a student as part of a design competition within the course, under which is the forum navigation. Below that is the live-feed showing forum activity in real time. Posts from participants are stored at the bottom of the page in three columns. Posts move left to right and top to bottom, as new content is submitted. This ensures new content is always at the top of the pinboard. Figure 1 (right) depicts a screen capture from a forum gallery. The screen capture shows the gallery profile image and description at the top of the page, followed by thumbnail previews of student submissions. Individual submissions can be viewed in full screen, and can be 'liked', commented on, and added to 'myCafe'.

Table 3. Student responses to questions and statements. The survey used a 5-point Likert scale from 1 (strongly disagree), to 3 (undecided), to 5 (strongly agree); BA = broad agreement.

\begin{tabular}{|l|c|c|c|}
\hline & Local Students & $\begin{array}{c}\text { International } \\
\text { Students }\end{array}$ & All Students \\
\hline Topic & BA & BA & BA \\
\hline $\begin{array}{l}\text { I believe Facebook is an effective host site for an } \\
\text { online and collaborative learning environment. }\end{array}$ & $73 \%$ & $80 \%$ & $74 \%$ \\
\hline $\begin{array}{l}\text { I believe academic and personal activities in } \\
\text { Facebook should be kept separate. }\end{array}$ & $67 \%$ & $73 \%$ & $68 \%$ \\
\hline $\begin{array}{l}\text { I am looking forward to using the Café learning } \\
\text { environment within Facebook this semester. }\end{array}$ & $72 \%$ & $100 \%$ & $75 \%$ \\
\hline
\end{tabular}
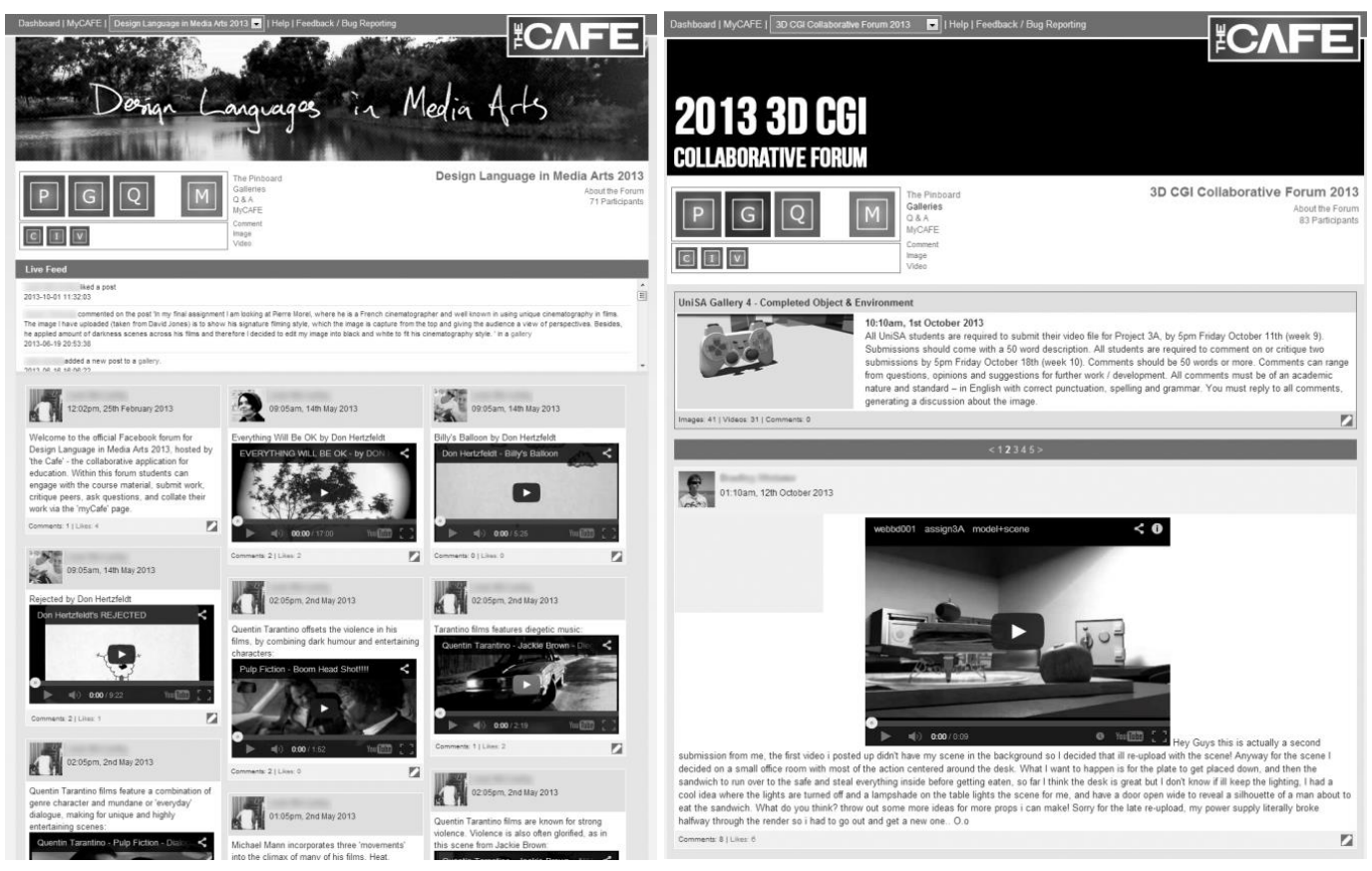

Figure 1. Left) a screen capture of the forum pinboard. Right) a screen capture of a forum gallery.

Figure 2 (left) shows a screen capture from the forum's $Q$ \& A page. The screen capture shows a list of questions asked by participants in reverse chronological order, ensuring new questions are 
at the top of the page. Any participant can provide a response to a question. Figure 2 (right) shows a screen capture from a student's myCafe page. Content within the 'myCafe' page is arranged in three columns: 'my posts' - every post made by the participant; 'commented posts' - every post which the participant has commented on; and 'added posts' - every post which the participant has chosen to 'add' to 'myCafe'.
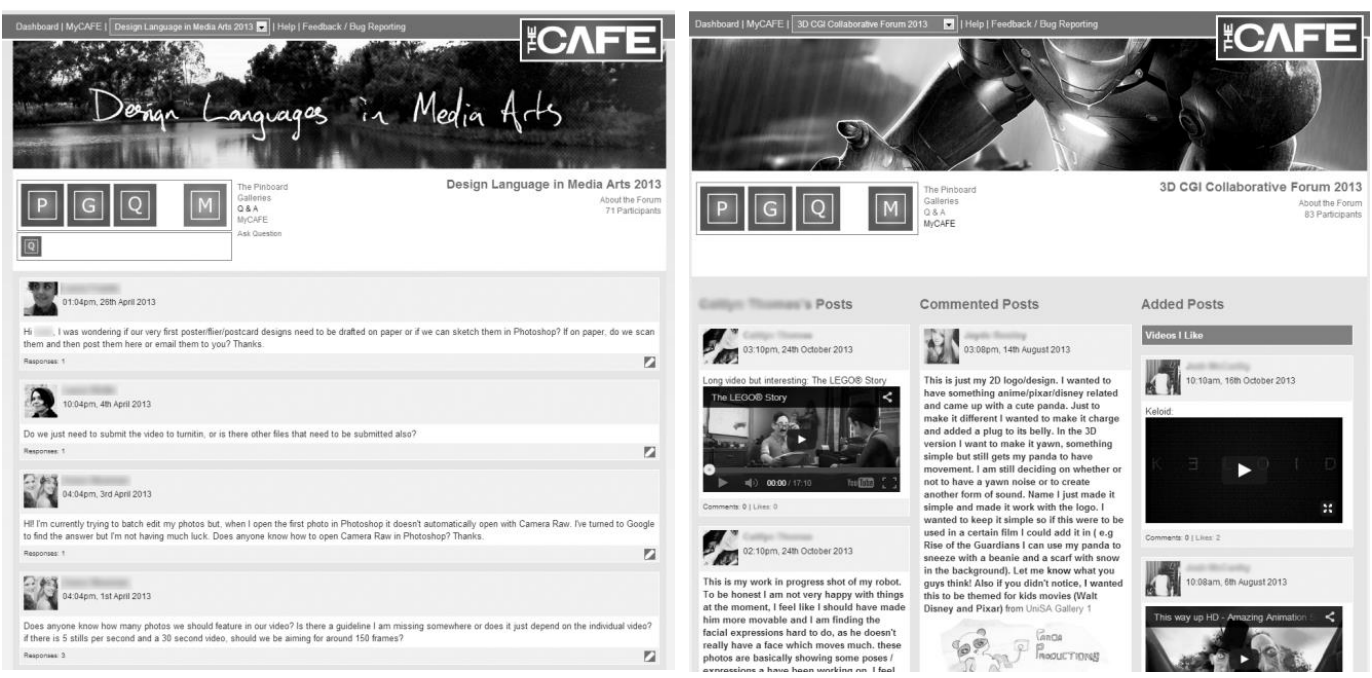

Figure 2. Left) a screen capture of the $Q$ \& A page. Right) a screen capture of a student's myCafe page.

The student experience during the two studies was evaluated through an online, ten-question, post semester survey. The post semester questionnaire addressed the design and functionality of the application; the perceived effectiveness of the learning environment; and the students' experiences throughout the semester. Students were invited to participate in the survey via the Café application and also via email. The survey remained open for a period of three weeks. Seventy students participated in the survey, again a response rate of 77 percent. Participants were given the opportunity to assess the learning experience in the form of likert-scale statements and open-ended questions. Broad agreement statistics, related to the six likert-scale statements are shown in Table 4.

Table 4. Student responses to questions and statements from the post-semester survey; BA = broad agreement.

\begin{tabular}{|l|c|c|c|}
\hline & $\begin{array}{c}\text { Local } \\
\text { Students }\end{array}$ & $\begin{array}{c}\text { International } \\
\text { Students }\end{array}$ & $\begin{array}{c}\text { All } \\
\text { Students }\end{array}$ \\
\hline Topic & BA & BA & BA \\
\hline $\begin{array}{l}\text { I would like to use the Café as an online learning environment } \\
\text { again in future courses. }\end{array}$ & $93 \%$ & $100 \%$ & $94 \%$ \\
\hline During the semester the Café promoted interaction with peers. & $91 \%$ & $100 \%$ & $93 \%$ \\
\hline $\begin{array}{l}\text { During the semester I received beneficial feedback through the } \\
\text { Café galleries. }\end{array}$ & $84 \%$ & $93 \%$ & $85 \%$ \\
\hline Having all of my posts collated in myCafe was beneficial. & $84 \%$ & $87 \%$ & $85 \%$ \\
\hline $\begin{array}{l}\text { During the semester the Café generated rewarding academic } \\
\text { discussions. }\end{array}$ & $78 \%$ & $93 \%$ & $80 \%$ \\
\hline $\begin{array}{l}\text { The ability to collate and categorise other students' posts in } \\
\text { myCafe was beneficial. }\end{array}$ & $75 \%$ & $80 \%$ & $76 \%$ \\
\hline
\end{tabular}


The questionnaire outlined student reactions towards the online learning environment in the Cafe. 85 percent of all participants indicated they received beneficial feedback from their peers during the semester while 80 percent noted the learning environment generated rewarding academic discussions. Responses included:

The Cafe is a great environment for promoting student discussion and sharing of ideas and thoughts on other students' work. It was good to hear different perspectives on the work I uploaded and to be able to provide feedback for other students, as well. (Local student).

Yes, I received many comments on my work from other students which was really great and helped me in my design work. (International student).

I really enjoyed being able to watch everyone's progress and abilities develop over the time of the course. (International student).

The majority of students, 93 percent, indicated the Café promoted interaction with their peers, by providing students with a familiar and accessible online environment:

Without the Café app, there would probably be less natural inclination among the students to discuss each other's work, but because the Café operates through Facebook, which is an environment that a lot of people are familiar with, I think people felt more comfortable with discussing their thoughts and ideas with each other. (Local student).

Providing students with design activities beyond the course assessment was also instrumental in promoting interaction between peers online:

The banner contest and 50 word comment rule are very peer interactive. There was always something to do or discuss during the semester on the Café. (International student).

Many participants responded positively towards myCafe, the personalised space within the Café, citing the ability to collate both posts from the pinboard, their own work and also peers' posts from the galleries:

It was helpful to collect the posts from the pinboard - images and videos related to assignments or lectures. (International student).

The Café proved to be popular with participants as 94 percent indicated they wanted to use the onlinelearning environment again in the future, referring to the application's ability to generate peer discussions, to learn about design, and to promote group learning:

I really like the way our course interacted with the Café, it's nice to see the uni using available technologies. (Local student).

Definitely - this was a good way to get everyone learning together. (International student).

A large number of students, predominantly international students, noted that the online environment gave them more time to think and react, as opposed to a traditional classroom:

As an international student it is hard sometimes to discuss in class. It is great to get so many comments from other students and staff. (International student).

The Café is excellent because we have our critiques written down, and we can read through and comment at our own pace. (International student). 
Many participants responded positively when asked about the design, layout and navigation of the Café:

Great, simple to navigate and understand. A good layout. A great tool to see peers' work. (International student).

The Café is easy to navigate through and that is credited to the simple design layout. (Local student).

While the majority of students enjoyed participating in the online environment, and believed they benefitted from doing so, there was a small number of students who simply did not. When asked to provide details on any problem areas, concerns, or room for improvement in the design and functionality of the Café, students noted loading times and upload errors related to specific video types as key issues:

The only problem would be sometimes there are issues with uploading videos and sometimes uploaded videos wouldn't play straight away. (Local student).

Sometimes the pages took a while to load because they contained large files. (International student).

The only thing that I find annoying is that I have to enter the DLMA [the course: Design Language in Media Arts] forum when I launch the Café instead of it taking me straight there. (Local student).

Final reflections on the learning experience provided insight into how the Café could grow in the future:

The Café allows me to be inspired by some really creative works. (International student).

At the start of the semester I was very sceptical in regards to the whole 'Facebook idea', but it actually worked really well. It is almost surprising for someone like me who still uses a very old Nokia without internet! (International student).

\section{Discussion}

The majority of participants responded positively towards the learning experience within the Café at the conclusion of the pilot studies. The international student respondents were particularly positive towards the experience, as outlined in Table 4, noting the professional design and simple navigation as two key features of the application, while its accessibility (via Facebook) and interactivity (through posting, commenting on, and collating content) were also important in providing a platform for discussing their design work and interacting with peers, especially local students. This online interaction helped the development of cross-cultural relationships. Such relationships are particularly important for commencing international students, who can struggle to develop meaningful connections with local students, often due to language barriers. The addition of a virtual environment enabled international students to formulate meaningful comments and critiques, as opposed to rushing immediate responses under pressure in the classroom.

Transnational education has grown rapidly in recent years, both in Australia and around the world. In 2009, almost 3.7 million tertiary students were enrolled to study outside their country of citizenship, increasing four fold from 0.8 million in 1975 (OECD, 2014). Furthermore, in 2009, more than one in five (22 percent) tertiary education students in Australia were international students (OECD, 2014). This is the highest proportion of international students in all countries within the 
Organisation for Economic Co-operation and Development (OECD) followed by the United Kingdom (15 percent) and Austria (15 percent). Australia's share of the international student market increased from 5.1 percent in 2000 to 7.0 percent in 2009, (OECD, 2014) making Australia the third largest provider of international education services in 2009, behind the United States (18 percent), and the United Kingdom (10 percent). Considering the relative size of Australia's population, such high representation amongst the international student market is indicative of the ongoing importance of this sector to Australia, both economically and for communities (ABS, 2014).

Given the important contribution the international student sector makes to Australia's economy and society, ensuring the future strength of the industry is an ongoing priority for government (ABS, 2014). Information and Communication Technologies (ICT), such as the Café, have the capacity to improve the learning experience of international students by providing a platform for academic and social interaction with peers, staff and mentors. Such interactions are crucial in ensuring a successful and enjoyable student experience and are aligned with the 'quality of education' action area within the Council of Australian Government's (COAG) International Students Strategy for Australia (2010-2014) (COAG, 2014).

Research and development of the Café will continue in the future and forthcoming publications will focus on revisions to the design and operation of the application, as well as additional case studies using it as an e-learning environment. Collaborative learning partnerships in the Café will continue in the future including student cohorts from the University of South Australia, Swinburne University and Queensland University of Technology, participating in a joint learning forum.

\section{Notes}

1 A shorter version of this paper was presented as a background paper at the 2014 Global Conference for Teaching and Learning with Technology, July 9-10, Singapore, 2014.

\section{References}

ABS, (2014). Australian Social Trends. Available at: http://www.abs.gov.au [Accessed 30 June 2014]. Baloglu, M. (2000). Expectations of international students from counseling services. Paper presented at the Annual Conference on the American Psychological Association, Washington DC, USA.

Bosch, T. E. (2009) Using online social networking for teaching and learning: Facebook use at the University of Cape Town. Communication: South African Journal for Communication Theory and Research,35 (2), 185-200.

Council of Australian Governments (COAG) (2014). International Students Strategy for Australia. Available at http://coag.gov.au [Accessed 30 June 2014].

Deng, L., \& Taveres, N. (2013). From Moodle to Facebook: Exploring students' motivation and experiences in online communities. Computers \& Education. 68, 167-176.

Duffy, P. (2011) Facebook or faceblock. In C. McLoughlin \& M. Lee (Eds.). Web 2.0 Based e-learning: Applying Social Informatics for Tertiary Teaching, pp.284-300.

Hojat, M. (1982). Loneliness as a function of selected personality variables. Journal of Clinical Psychology, 38 (1), 137-141.

Irwin, C., Ball, L., Desbrow, B. and Leveritt, M. (2012) Students' perceptions of using Facebook as an interactive learning resource at university. Australasian Journal of Educational Technology, $27(8), 1221-1232$.

Kenney. J, Kumar, S, and Hart, M., (2013). Facebook group as a space for interactive and collaborative learning. International Journal of Social Media and Interactive Learning Environments, 1(4), 355-369.

Krause, K., (2006). Making connections in the First Year: The key to Success in An Age on Unreason, Keynote paper presented at the Nineteenth International Conference on The First-Year Experience, Toronto, Ontario, Canada. 
Kurtz, G., (2013). Facebook group as a space for interactive and collaborative learning. International Journal of Social Media and Interactive Learning Environments, 1(4), 406-418.

Mazman, S. G. and Usluel, Y. K. (2010) Modeling educational usage of Facebook. Computers and Education, 55(2), 444-453.

McCarthy, J. (2009) Utilising Facebook: immersing Generation-Y students into first year university, Journal of the Education Research Group of Adelaide, 1(2), 39-49.

McCarthy, J. (2010) Blended learning environments: Using social networking sites to enhance the first year experience. Australasian Journal of Educational Technology, 26(6), 729-740.

McCarthy, J. (2012). Online networking: integrating international students into first year university, in F. Jose Garcia (Ed.) Multiculturalism in Technology-Based Education: Case Studies on ICTSupported Approaches, Hershey, PA: IGI Global, pp189-210

McCarthy, J., (2013a). Learning in Facebook: First year tertiary student reflections from 2008 to 2011. Australasian Journal of Educational Technology, 29(3), 337-356.

McCarthy, J., (2013b). The Café: creating the 'collaborative application for education'; a dedicated e-learning environment in Facebook. International Journal of Social Media and Interactive Learning Environments, 1(4), 419-438.

OECD (2014). Who Studies Abroad and Where. Available at http://oecd.org. [Accessed 30 June 2014].

Osterman K.F. (2000) Student's Need for belonging in the School's Community. Review of Educational Research, 70 (3), 323-367.

Rambe, P. (2012) Critical discourse analysis of collaborative engagement in Facebook postings. Australasian Journal of Educational Technology, 28 ( 2), 295-314.

Richardson, W. (2006) Blogs, Wikis, Podcasts, and Other Powerful Tools for Classrooms. Thousand Oaks, CA: Sage.

Ritter, N, and Delen, E., (2013). Undergraduates' Facebook use: evidence-based practice to implement social media in education. International Journal of Social Media and Interactive Learning Environments, 1(4), 387-405.

Sarason, B., Sarason, I., \& Gurung, R. (1997). Close personal relationships and health outcomes: A key to the role of social support. In S. W. Duck (Ed.), Handbook of personal relationships: Theory, research and intervention ( $2^{\text {nd }}$ ed). Chicester, UK: Wiley, pp.547-573

Sawir, E., Marginson, S., Deumert, A., Nyland, C., \& Ramia, G. (2008). Loneliness and international students: An Australian study. Journal of Studies in International Education. 12 (2), 148-180.

Shih, R.-C. (2011) Can Web 2.0 technology assist college students in learning English writing?. Australasian Journal of Educational Technology, 27(5), 829-845.

Statistics Brain (2014). Facebook Statistics. Available at: http://www.statisticsbrain.com [Acessed 30 June 2014].

Stokes, J. (1985). The relation of social network and individual difference variables to loneliness. Journal Personality and Social Psychology, 48(4), 981-990.

Wang, Q.Y., Woo, H.L., Quek, C.L., Yang, Y.Q., and Liu, M. (2012) Using the Facebook group as a learning management system: An exploratory study. British Journal of Educational Technology, 43(3),428-438.

Weiss, R. (1973). Loneliness: The experience of emotional and social isolation. Cambridge, MA: MIT Press. 